\title{
Ecology and life history of Meta bourneti (Araneae: Tetragnathidae) from Monte Albo (Sardinia, Italy)
}

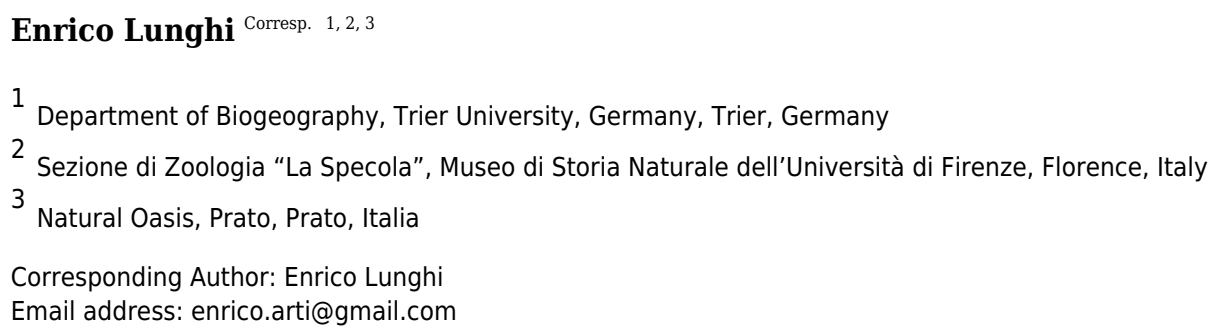

The orb-weaver spider Meta bourneti Simon 1922 (Araneae: Tetragnathidae) is one of the most common cave predators occurring in the Mediterranean basin. Although the congeneric $M$. menardi represented the model species in several studies, our knowledge of $M$. bourneti is only founded on observations performed on a handful of populations. In this study M. bourneti spiders were studied in caves of Monte Albo (Sardinia, Italy) over a year. Generalized Linear Mixed Models were used to analyze spider occupancy inside cave environments, as well as spider abundance. Analyses on M. bourneti occupancy and abundance were also repeated for adults and juveniles separately. Generalized Linear Models, were used to weight species absence based on its detection probability. Linear Mixed Models were used to detect possible divergences in underground spatial use between adult and juvenile spiders. Although widespread on the mountain, $M$. bourneti generally showed low density and low detection probability. Most of the individuals observed were juveniles. The spiders generally occupied cave sectors with high ceilings that were deep enough to show particular microclimatic features. Adults tended to occupy less illuminated areas than juveniles, while the latter were more frequently found in sectors showing high humidity. The abundance of $M$. bourneti was strongly related to high humidity and the presence of two troglophile species, Hydromantes flavus Wake, Salvador \& Alonso-Zarazaga, 2005 (Amphibia: Caudata) and Oxychilus oppressus (Shuttleworth, 1877) (Gastropoda: Panpulmonata). The abundance of juveniles was related to sector temperature and humidity, the presence of $H$. flavus and $O$. oppressus and to morphological sector features. However, when only adults were considered, no significant relationships were found. Adult and juvenile spiders did not differ in their spatial distribution inside the caves studied, but a seasonal distribution of the species along cave walls was observed. Microclimate was one of the most important features affecting both the presence and abundance of $M$. bourneti in underground environments. Individuals 
tended to occupy lower heights during hot seasons. 
1 Ecology and life history of Meta bourneti (Araneae: Tetragnathidae) from Monte Albo

2 (Sardinia, Italy)

3 Enrico Lunghi ${ }^{1,2,3 *}$

4

$5{ }^{1}$ Universität Trier Fachbereich VI Raum-und Umweltwissenschaften Biogeographie, Campus I,

6 Gebäude N Universitätsring 15, 54286 Trier, Germany

$7 \quad{ }^{2}$ Museo di Storia Naturale dell’Università di Firenze, Sezione di Zoologia “La Specola", Via

8 Romana 17, 50125 Firenze, Italia

$9 \quad{ }^{3}$ Natural Oasis, Via di Galceti 141, 59100 Prato, Italia

10

11 *Corresponding author. Tel.:+39 3391604627

12 E-mail address: enrico.arti@gmail.com 


\section{Abstract}

15 The orb-weaver spider Meta bourneti Simon 1922 (Araneae: Tetragnathidae) is one of the most

16 common cave predators occurring in the Mediterranean basin. Although the congeneric $M$.

17 menardi represented the model species in several studies, our knowledge of $M$. bourneti is only

18 founded on observations performed on a handful of populations. In this study M. bourneti spiders

19 were studied in caves of Monte Albo (Sardinia, Italy) over a year. Generalized Linear Mixed

Models were used to analyze spider occupancy inside cave environments, as well as spider

abundance. Analyses on M. bourneti occupancy and abundance were also repeated for adults and juveniles separately. Generalized Linear Models, were used to weight species absence based on its detection probability. Linear Mixed Models were used to detect possible divergences in underground spatial use between adult and juvenile spiders. Although widespread on the mountain, M. bourneti generally showed low density and low detection probability. Most of the individuals observed were juveniles. The spiders generally occupied cave sectors with high ceilings that were deep enough to show particular microclimatic features. Adults tended to occupy less illuminated areas than juveniles, while the latter were more frequently found in sectors showing high humidity. The abundance of $M$. bourneti was strongly related to high humidity and the presence of two troglophile species, Hydromantes flavus Wake, Salvador \& Alonso-Zarazaga, 2005 (Amphibia: Caudata) and Oxychilus oppressus (Shuttleworth, 1877) (Gastropoda: Panpulmonata). The abundance of juveniles was related to sector temperature and humidity, the presence of H. flavus and O. oppressus and to morphological sector features. However, when only adults were considered, no significant relationships were found. Adult and juvenile spiders did not differ in their spatial distribution inside the caves studied, but a seasonal distribution of the species along cave walls was observed. Microclimate was one of the most 
37 important features affecting both the presence and abundance of $M$. bourneti in underground

38 environments. Individuals tended to occupy lower heights during hot seasons. 
39

40

41

42

43

44

\section{INTRODUCTION}

Underground environments, from shallow cracks and burrows to the deepest karst systems, are peculiar habitats showing a characteristic combination of environmental features. They generally show little or no light, high air humidity and a relatively stable temperature resembling the mean annual temperature occurring in outdoor surrounding areas (Culver \& Pipan, 2009; Smithson, 1991). Underground microclimate is generally shaped by the influence of external climate which, through openings connecting underground environments with outer ones, spread in and contribute to creating different microhabitats (Badino, 2004; Badino, 2010; Campbell Grant, Lowe \& Fagan, 2007; Lunghi, Manenti \& Ficetola, 2015). The most evident result is the formation of three different macro-ecological zones (Culver \& White, 2005). The zone adjacent to the connection with the outdoor is the most affected by external influences. Indeed, the microclimate of this area generally resembles environmental conditions occurring in surrounding outdoor areas. In the "twilight zone" external influences are weaker and incoming light is generally low. Finally, there is the deep zone, where incoming light is absent and microclimatic features are the most stable.

Underground environments house a rich biodiversity of species that display unique and peculiar adaptations to the different ecological zones (Romero, 2011). A species' degree of association to subterranean conditions is the basis for the general ecological classification used to distinguish between different groups of cave-dwelling organisms (Christiansen, 1962; Novak et al., 2012; Pavan, 1944; Sket, 2008). Several additional descriptors are used to classify cave animals (Trajano \& de Carvalho, 2017). The most specialized are called troglobites, species closely connected to the deep areas of subterranean environments. Troglobites often show specific adaptations, such as depigmentation, anophthalmia, elongation of appendages, and a 
62 reduction in metabolic rates (Aspiras et al., 2012; Bilandžija et al., 2013; Biswas, 2009; Hervant,

63 Mathieu \& Durand, 2000). In contrast, troglophiles can exploit both epigan and hypogean

64

environments and their adaptations to cave life are reduced or even absent (Di Russo et al., 1999;

Fenolio et al., 2006; Lunghi, Manenti \& Ficetola, 2017). Trogloxenes are epigean species accidentally found in the shallowest part of subterranean environments. This classification, however, is viewed too strict (Lunghi, Manenti \& Ficetola, 2014; Romero, 2009), as species usually thought to be accidental are indeed potential residents playing an important role throughout the entire ecosystem (Lunghi et al., 2018a; Manenti, Lunghi \& Ficetola, 2017; Manenti, Siesa \& Ficetola, 2013).

Despite an increasing interest in subterranean ecological spaces and their related biodiversity that has occurred in the last decades (Culver \& Pipan, 2009; Culver \& Pipan, 2014; Juan et al., 2010; Romero, 2009), our current knowledge of cave-dwelling species is incomplete. For example, there is the case of the troglophile orb-weaving spider Meta bourneti Simon 1922 (Araneae, Tetragnathidae). Meta spiders are among the most common predators in cave environments (Mammola \& Isaia, 2017b; Mammola, Piano \& Isaia, 2016; Manenti, Lunghi \& Ficetola, 2015; Pastorelli \& Laghi, 2006). These spiders show an interesting complex life history. During their early life stages they are phototaxic and disperse in outdoor environments, while during the adult phase they become photophobic and inhabit subterranean environments, where they reproduce (Chiavazzo et al., 2015; Smithers, 2005b; Smithers \& Smith, 1998; but see also Fig. 6 in Mammola \& Isaia, 2014). Meta spiders are at the apex of the subterranean foodchain, preying on several species using both web and active hunting (Lunghi, Manenti \& Ficetola, 2017; Mammola \& Isaia, 2014; Novak et al., 2010; Pastorelli \& Laghi, 2006; 
84 Smithers, 2005a; Tercafs, 1972). However, young spiders are potential prey of other cave 85 predators (Lunghi et al., 2018b).

86

87

In Europe and the Mediterranean basin area, two species of Meta spiders are commonly observed, M. menardi and M. bourneti (Fernández-Pérez, Castro \& Prieto, 2014; Fritzén \& Koponen, 2011; Mammola \& Isaia, 2014; Nentwig et al., 2018). Although the former is the subject of several studies (Ecker \& Moritz, 1992; Hörweg, Blick \& Zaenker, 2012; Lunghi, Manenti \& Ficetola, 2017; Mammola, Piano \& Isaia, 2016; Manenti, Lunghi \& Ficetola, 2015), research on M. bourneti is very limited (Boissin, 1973; Mammola, 2017; Mammola \& Isaia, 2017a). In a recent study, Mammola and Isaia (2014) studied the distribution and abundance of M. menardi and M. bourneti in six caves located in the north-west of Italy. Although they confirmed the previously hypothesized similarities in habitat selection between the two cavedwelling Meta spiders (Gasparo \& Thaler, 1999), M. bourneti was present at warmer temperatures. In addition, it displayed a shift in its life cycle compared to the congeneric $M$. menardi, which likely resulted from competition between the two species (Mammola \& Isaia, 2014).

The present study provides the first report of the ecology and life history of M. bourneti populations from Sardinia (Italy). In this area the congeneric $M$. menardi is not present and thus, no potential interspecific interactions limit habitat selection of M. bourneti (Mammola \& Isaia, 2014; Nentwig et al., 2018). This study aims to produce information related to: $i$ ) Improve our understanding of the effect of abiotic and biotic factors on both the occupancy and abundance of M. bourneti in subterranean environments, $i i)$ document the spatial distribution of these spiders within caves, iii) identify differences between life stages (juveniles vs adults), and $i v$ ) gather and summarize information on the life history of the species. 


\section{MATERIALS \& METHODS}

109

110

111

112

113

114

115

116

117

118

119

120

121

122

123

124

125

126

127

\section{Dataset}

The analyzed dataset focuses on M. bourneti observed in caves from the Monte Albo (north-east Sardinia, Italy) (Fig.1; Table S1). Data were collected from seven different caves. However, $M$. bourneti was not observed in one of the caves and the cave was not included in the analysis. Surveys were performed seasonally, from autumn 2015 to summer 2016, thus covering a full year. Two samplings, 1-7 days apart, were conducted each season. Using a meter tape, inner cave environments were divided horizontally into $3 \mathrm{~m}$ sections (hereafter, sector), to collect fine-scale data on both cave morphology and microclimate, as well as on the occurrence of other cavedwelling species (Ficetola, Pennati \& Manenti, 2012; Lunghi, Manenti \& Ficetola, 2017). Caves were explored entirely or up to the point reachable without speleological equipment. Within each cave sector the following abiotic data were recorded: maximum height and width, wall irregularity, average temperature $\left({ }^{\circ} \mathrm{C}\right)$, humidity $(\%)$ and illuminance (lux). Maximum height and width were recorded at the end of each sector using a laser meter (Anself RZE-70, accuracy 2 $\mathrm{mm}$ ). At each of these sampling points wall heterogeneity (i.e., presence of wall protuberance) was measured by placing a one-meter length of string along the cave wall at each of the sampling points between $0.5-2 \mathrm{~m}$ of height. The string was unrolled vertically following the shape of the cave wall, and the linear distance between the two string extremities (measured with a meter tape) quantified the smoothness of the wall (Ficetola, Pennati \& Manenti, 2012; Lunghi, Manenti \& Ficetola, 2014). During each survey, inner microclimatic data were recorded using a Lafayette TDP92 thermo-hygrometer (accuracy: $0.1^{\circ} \mathrm{C}$ and $0.1 \%$ ). At the end of each cave sector, the average air temperature and humidity were estimated by merging data recorded in two 
130 different points: at ground level and at $2.5 \mathrm{~m}$ of height (or at the ceiling if sector height was

131 lower). Microclimatic data were recorded paying attention to limit operator influence (Lopes

132 Ferreira et al., 2015). At the same point, the maximum and minimum incident light using a

133 Velleman DVM1300 light meter (minimum recordable light: 0.1 lux) was also measured. A

134 standardized survey method (7.5 min/sector) was used to collect data on the presence of six cave-

135 dwelling species: M. bourneti, Hydromantes flavus Wake, Salvador \& Alonso-Zarazaga, 2005

136 (Amphibia: Caudata), Metellina merianae Scopoli, 1763 (Arachnida: Araneae), Tegenaria sp.

137 Latreille, 1804 (Arachnida: Araneae), Oxychilus oppressus (Shuttleworth, 1877) (Gastropoda:

138 Panpulmonata) and Limonia nubeculosa Meigen, 1804 (Insecta: Diptera). These species likely

139 interact with Meta spiders, as they represent both potential prey and predators (Lunghi et al.,

140 2018b; Manenti, Lunghi \& Ficetola, 2015; Novak et al., 2010). Meta spiders were also counted

141 and ascribed to two different categories on the basis of body size (prosoma + opisthosoma):

142 adults with fully developed pedipalps (body size $\geq 10 \mathrm{~mm}$ ) and juveniles (body size $<10 \mathrm{~mm}$ )

143 (Bellmann, 2011; Mammola \& Isaia, 2014; Nentwig et al., 2018). The number of observed

144 cocoons was also recorded.

\section{Data analyses}

147 The following analyses were performed in the open source statistical computing program $\mathrm{R}(R$

148 Core Team, 2016). Analyses on detection probability, species-habitat association and abundance

149 were performed three times, one for each group studied (all individuals, adults only and juveniles

150 only). Data for modeling species occurrence and abundance, was only related to surveys in

151 which microclimatic features were recorded (cave surveys $=31, N$ of spiders $=110$ ). 
153

154

155

156

157

158

159

160

161

162

163

164

165

166

167

168

169

170

171

172

173

\section{Detection probability}

Cave spiders are among the species showing imperfect detection: a species is present when it is observed, but a lack of observation does not mean its true absence (MacKenzie et al., 2006). The detection probability of $M$. bourneti was estimated on the basis of twenty-seven pairs of cave surveys (i.e., 624 pairs of cave sectors) performed during each season with a gap $\leq 7$ days (R package unmarked; Fiske \& Chandler, 2011), a prerequisite for population closure (i.e., no immigration or emigration occurs; MacKenzie et al., 2006). Three possible covariates influencing spider detection were considered: the depth of the cave sector (hereafter, depth), the season and the wall heterogeneity. Four models were built, one for each covariate and one with none (i.e., the null model), and then ranked following the Akaike's Information Criterion (AIC); the one with the lowest AIC value was used to estimate detection probability (Burnham \& Anderson, 2002; Burnham, Anderson \& Huyvaert, 2011).

\section{Analyses on species occurrence}

Binomial Generalized Linear Mixed Models (GLMM) (R packages lme4, lmerTest, MASS, MuMIn; Bartoń, 2016; Douglas et al., 2015; Kuznetsova, Brockhoff \& Christensen, 2016; Venables \& Ripley, 2002) were used to assess the relationship between Meta spiders and the abiotic features characterizing the cave environments. The presence/absence of the spiders was used as a dependent variable, while sector morphology (height, width and wall heterogeneity) and microclimatic features (temperature, humidity and illuminance) were used as independent variables. To evaluate whether spiders' preferences change through the year, the interaction 
174 between season and each of the considered microclimatic features was also included as an

175 independent variable. Sector and cave identity were used as random factors. For each studied

176 group, GLMMs were built using all possible combinations of independent variables; such

177 models were then ranked following the Akaike's Information Criterion corrected for small

178 sample size (AICc) (Fang, 2011). The model showing the lowest AICc value was considered the

179 best model. Following the recommendations of Richards, Whittingham and Stephens (2011),

180 models representing more complicated versions of those with a lower AIC value and nested

181 models were not considered as candidate models. The likelihood ratio test was used to assess the

182 significance of variables included in the best AICc models. Before analyses, humidity was

183 angular-transformed and illuminance log-transformed, to improve linearity.

184 Considering a potential variation in species-habitat association over time (Lunghi,

185 Manenti \& Ficetola, 2015; Lunghi, Manenti \& Ficetola, 2017) and an overall low detection

186 probability estimated for these spiders, the robustness of the previous analyses was tested using a

187 method that allows weighting the species absence on the basis of its detection probability: the

188 General Linear Models (GLM) (Gómez-Rodríguez et al., 2012). Adding random factors to this

189 analysis is not possible, hence the cave identity was included as a fixed factor. Following the

190 same procedure described above, for each species all possible GLMs were built and ranked

191 following AICc. The significance of variables included in the best AICc model was tested using

192 the likelihood ratio test (Bolker et al., 2008).

GLM analysis was repeated for each group including depth as a further independent

variable, as for some groups the best AICc model estimating detection probability included sector depth. 
197

198

200

201

202

203

204

205

206

207

208

209

210

211

212

213

214

215

216

217

\section{Analyses of species abundance}

The relationship between abundance of $M$. bourneti and both microclimatic and biotic recorded parameters was examined using GLMMs. The observed abundance of spiders was used as a dependent variable, as it represents an index of true abundance (Barke et al., 2017). Season, along with both microclimatic (average temperature, humidity and illuminance) and biotic (presence/absence of the five considered species) features, were included as independent variables, while sector and cave identity were included as random factors. The significance of variables was tested with a Likelihood ratio test.

\section{Analyses on spatial distribution}

Two Linear Mixed Models (LMM) (R package nlme; Pinheiro et al., 2016) were used to test whether adult and juvenile $M$. bourneti show divergences in the spatial use of subterranean environments; spiders' age class (adult/juveniles) and season were used as independent factors, and both sector and cave identity as random factors. The two dependent variables were the distance from the cave entrance and the height above cave floor, respectively. The dataset used in this analysis is shown in Table S2.

\section{RESULTS}

Overall, a total of 182 observations of M. bourneti (64 adults and 118 juveniles) were performed within the caves studied (mean $\pm \mathrm{SE}=30.33 \pm 16.49$ per cave). Observations of spiders were highest in spring (3.17 spiders/visit), followed by winter (2.92 spiders/visit), 
218 summer (2.67 spiders/visit) and autumn (1.92 spiders/visit) (Fig. 2). Of 1,958 cave sector

219 surveys, spiders were observed on 155 occasions, with generally one spider occupying the cave

220 sector (132) (Table S2). Occupied cave sectors showed the following microclimatic conditions:

221 average temperature $=14.47 \pm 0.16^{\circ} \mathrm{C}(\min -\max ; 11.25-19.45) ;$ average humidity $=91.20 \pm 0.3$

$222 \%(80.6-94.3)$; average illuminance $=2.55 \pm 1.8$ lux (0-156.05). In only two cases two adults

223 shared the same cave sector, while juveniles did this more frequently (4 times with an adult and

22419 with other juveniles). Two cocoons were observed during autumn, each in a different cave.

225 One of these was observed lying on the ground, already with numerous recently hatched spiders;

226 during winter, spiderlings abandoned the cocoon. No further information on the second cocoon

227 was available.

228

Detection probability of $M$. bourneti

In species analysis, the model including depth as covariate was the best model (AICc =

753.38) compared to the other three models (model including season, AICc $=755.72$; model

232

including wall heterogeneity, AICc $=756.02$; null model, $\mathrm{AICc}=756.24)$. Meta bourneti

showed an overall low detection probability (0.225). Considering adults only, the model

(model including season, $\mathrm{AICc}=389.71$; model including wall heterogeneity, $\mathrm{AICc}=389.71$;

null model, AICc $=387.74)$. Adults showed a very low detection probability $(0.108)$. Finally, for

559.02) compared to the other three models (model including depth, AICc $=561.78$; model juvenile M. bourneti was 0.164 . 
Results of the two analyses (GLMM and GLM) were consistent, thus showing a

244

245

246

247

248

249

250

251

252

253

254

255

256

257

258

259

260

261

262

substantial similarity in the identification of significant variables (Tables 1 and 2). The occurrence of $M$. bourneti was positively related to sector height and humidity. The best GLMM also included the season and the interaction between season and illuminance. Site was also included in the best GLM (Tables 1 and 2). The occurrence of adult spiders was negatively related to illuminance (Tables 1 and 2). The occurrence of juvenile spiders was positively related to sector height and humidity; a significant relationship with season was included in the best model of both analyses. The best GLMM also included a significant relationship between season and illuminance, while in the best GLM the site was also included (Tables 1 and 2).

Results of GLM including sector depth as a further independent variable were consistent with those of the previous GLM analyses (Tables S3 and S4).

\section{Spider abundance}

The abundance of $M$. bourneti was related to sector humidity $\left(F_{1,543.59}=6.7, P=0.01\right)$ season $\left(F_{3,566.23}=3.41, P=0.017\right)$ and the presence of Hydromantes flavus $\left(F_{1,672.34}=21.91, P<\right.$ $0.001)$ and Oxychilus oppressus $\left(F_{1,673.13}=22.55, P<0.001\right)$. Spiders were more abundant in spring, within cave sectors with high humidity and where $H$. flavus and O. oppressus were present. The abundance of adults showed no significant correlation with the variables considered. The abundance of juveniles was related to sector temperature $\left(F_{1,267.93}=4.22, P=0.041\right)$, humidity $\left(F_{1,561.55}=7.65, P=0.006\right)$, season $\left(F_{3,580.85}=4.27, P=0.005\right)$ and the presence of both 
263

264

265

266

267

268

269

270

271

272

273

274

275

276

277

278

279

280

281

282

283

284

H. flavus $\left(F_{1,673.15}=25.65, P<0.001\right)$ and $O$. oppressus $\left(F_{1,673.59}=29.73, P<0.001\right)$. Juvenile spiders were generally more abundant in spring, within warm cave sectors showing high humidity and where H. flavus and O. oppressus were present.

\section{Spider distribution}

Distance from the cave entrance did not differ between age classes $\left(F_{1,122}=0.26, P=\right.$ $0.608)$ nor between seasons $\left(F_{3,122}=0.58, P=0.626\right)$. Vertical distribution of spiders (i.e., height from the cave floor) did not differ between age classes $\left(F_{1,113}=0.85, P=0.358\right)$ but a significant effect of season was detected $\left(F_{3,113}=6.20, P<0.001\right)$; Meta spiders were generally at a lower height during spring and summer (Fig. 3).

\section{DISCUSSION}

Meta bourneti spiders represent one of the top predators commonly occurring in Monte Albo caves. Indeed, spiders were present in most of the subterranean environments sampled. The only cave of the dataset in which M. bourneti was never observed was located at an elevation exceeding 1000 meters above sea level. Probably, at this high elevation microclimatic conditions are unsuitable for the species (Lunghi et al., 2018d; Mammola \& Isaia, 2014). The largest number of spiders observed occurred in spring, a season in which invertebrates are generally more active (Bale \& Hayward, 2010). In the populations studied, the life cycle of M. bourneti seems to differ slightly from what was observed in north-western Italian populations (Mammola $\&$ Isaia, 2014). In September, the cocoon was already spun, and spiderlings started to emigrate in January. This possible variation in breeding phenology probably occurred because the two 
285 study areas are characterized by different climatic conditions (data derived from Hijmans et al.,

286 2005). It was recently shown that climatic conditions occurring at the surface can significantly

287 influence the subterranean breeding activity of troglophile species (Lunghi et al., 2018c).

288 However, the two data collections on M. bourneti were performed in different periods (2012-

2892013 in north-west Italy and 2015-2016 in Sardinia), it is therefore still unclear whether such a

290 divergence may be due to a change in local climate or to an annual fluctuation of climatic

291 conditions. In the future, an improvement in the number of cocoons observed, as well as in

292 repeated surveys over different years, will help in understanding whether populations of $M$.

293 bourneti show divergences in their life cycle.

Detection probability of $M$. bourneti was very low within cave sectors. Besides the low

295

296

297

298

299

300

301

302

303

304

305

306

307 density observed in the studied populations, some other environmental factors may have contributed in lowering spiders detectability (Nichols, Thomas \& Conn, 2008; Pollock et al., 2002). For example, the average ceiling height was usually too high for an exhaustive survey (average height $( \pm \mathrm{SD})=3.19 \pm 2.28 \mathrm{~m})$. Vertical movement of individuals could have put them in a position where they become difficult to detect (Nichols, Thomas \& Conn, 2008). In addition, another possibility is that the wall heterogeneity sheltered individuals, particularly smaller spiders, from being observed. Despite the general low detection probability, the adopted methodology of data analysis avoided potential biases due to such estimations and highlighted a high consistency of results obtained by both GLMMs and GLMs (Tables 1 and 2). Occurrence of M. bourneti was generally related to cave sectors showing high humidity. Sector humidity also positively affected the presence of juvenile spiders, while adults showed a high occurrence in cave sectors with low light (Table 2). These particular microclimatic conditions (high humidity and low illuminance) usually occur in cave areas far from the surface, where external influences 
308 are weaker and the microclimate is more stable (Culver \& Pipan, 2009; Lunghi, Manenti \&

309 Ficetola, 2015). As was pointed out for both M. bourneti and M. menardi, these spiders occupy

310 cave areas deep enough to show suitable microclimatic conditions, but still in the proximity of

311 sites with elevated prey abundance (Lunghi, Manenti \& Ficetola, 2017; Mammola \& Isaia,

312 2014; Manenti, Lunghi \& Ficetola, 2015). However, the tendency of M. bourneti to occupy cave

313 sectors with high ceilings is just the opposite of what was observed for M. menardi (Lunghi,

314 Manenti \& Ficetola, 2017). Considering that these two species show similar hunting strategies

315 (Mammola \& Isaia, 2014), the different preferences of cave sector morphology may be driven by

316 some other ecological factors. For example, in cave sectors with high ceilings, spiders may have

317 more surface (i.e., cave wall) to escape from potential predators present in the same cave sectors

318 (e.g., Hydromantes salamanders; Lunghi et al., 2018b). Indeed, sector height was particularly

319 significant for juveniles, while for adults this variable was not included in the best AICc model

320 (Tables 1 and 2).

Analyses of spider abundance identified both environmental and biological features as

potential determinants. In cave areas with high humidity, M. bourneti showed the highest

abundance. Furthermore, the presence of two other species (Hydromantes flavus and Oxychilus

oppressus) had a strong influence on spider abundance. While it is possible that $M$. bourneti

shares the same microhabitat preference with these species (Ficetola et al., 2018), trophic

interactions between M. bourneti and these two species may also explain this particular

association (Curry \& Yeung, 2013; Lunghi et al., 2018b; Mammola \& Isaia, 2014). However, available and thus, future studies are needed to shed light on this particular relationship. Overall, 
331 observations were related to juveniles $(\sim 66 \%)$ and this may have biased the analysis performed

332 at the species level. Indeed, results from the two analyses (all spiders and juveniles only) were

333 basically the same. When only adults were considered, no significant variables were detected.

334 No significant differences were found in the horizontal and vertical distribution between

335 age classes. Two spiders were rarely observed inside the same cave sector, and these

336 circumstances generally involved juveniles (Table S2). Information relating to the behavior of

337 this species is virtually absent; hence it is possible that individuals may be territorial, at least in

338 some populations. Considering the limited sample size analyzed here (Table S1), further studies

339 are needed to better comprehend the behavior of $M$. bourneti spiders. Seasonality did not affect

340 Meta spiders distribution along the horizontal development of the cave, but it strongly affected

341 the vertical distribution of all individuals (Fig. 3). During hot seasons, spiders were found closer

342 to the cave floor. Air circulation in cave environments is characterized by two main air layers,

343 where the lowest has a cooler temperature (Badino, 2010). Therefore, it may be that during hot

344 seasons the temperature of the upper layer becomes too high and spiders move toward the

345 ground floor looking for a more suitable microclimatic condition (Lunghi, Manenti \& Ficetola, 346 2017).

\section{CONCLUSION}

This study represents the first analysis performed on island populations of Meta bourneti, and was conducted with the aim of adopting a more complete approach to studying the different ecological aspects of these cave-dwelling spiders. Meta spiders were found to be widespread in

352 subterranean environments of Monte Albo, but with low densities. The species' life cycle, as 
353 well as the distribution of individuals inside caves, appears to be strongly dependent on local

354 climatic conditions, showing some divergences from mainland Italian populations. Microclimate

355 was one of the main features affecting both the presence and abundance of $M$. bourneti in

356 subterranean environments. Morphological cave features may help Meta spiders escape

357 unsuitable microclimatic conditions and avoid potential predators. During their subterranean

358 phase, spiders showed the same tendency to avoid the shallowest part of the caves (only one out

359 of 182 observed individuals was found within the first six meters), areas which likely have

360 unsuitable microclimatic conditions. The vertical movement of spiders during different seasons

361 suggests behavior that limits exposure to unsuitable microclimatic conditions. However, further

362 studies on populations from different geographical regions may help in provide a better overview

363 on the ecology of this widespread cave-dwelling species. 
364

365

366

367

368

369

370

371

372

373

374

375

376

377

378

379

380

381

382

383

384

385

386

387

388

389

390

391

392

393

394

395

396

397

398

399

400

401

402

403

404

405

406

407

408

409

410

411

\section{References}

Aspiras AC, Prasad R, Fong DW, Carlini DB, and Angelini DR. 2012. Parallel reduction in expression of the eye development gene hedgehog in separately derived cave populations of the amphipod Gammarus minus. Journal of Evolutionary Biology 25:995-1001. 10.1111/j.14209101.2012.02481.x

Badino G. 2004. Cave temperatures and global climatic change. International Journal of Speleology 33:103-114.

Badino G. 2010. Underground meteorology - "what's the weather underground?". Acta Carsologica 39:427-448.

Bale JS, and Hayward SAL. 2010. Insect overwintering in a changing climate. The Journal of Experimental Biology 213:980-994. 10.1242/jeb.037911

Barke RJ, Schofield MR, Link WA, and Sauer JR. 2017. On the reliability of N-mixture models for count data. Biometrics:1-9. 10.1111/biom. 12734

Bartoń K. 2016. MuMIn: Multi-Model Inference. $R$ package version 1156. https://CRAN.Rproject.org/package=MuMIn

Bellmann H. 2011. Guida ai ragni d'Europa. Roma: Franco Muzzio Editore.

Bilandžija H, Ma L, Parkhurst A, and Jeffery WR. 2013. A potential benefit of albinism in Astyanax cavefish: downregulation of the oca 2 gene increases tyrosine and catecholamine levels as an alternative to melanin synthesis. PLOS ONE 8:e80823. 10.1371/journal.pone.0080823

Biswas J. 2009. Kotumsar Cave biodiversity: a review of cavernicoles and their troglobiotic traits. Biodiversity and Conservation 19:275-289. DOI 10.1007/s10531-009-9710-7

Boissin L. 1973. Étude ultrastructurale de la spermiogenèse de Meta bourneti Simon (Arachnides, Aranéides, Metinae). Comptes Rendus deuxième de la Réunion Arachnologique d'Expression Française 7:22.

Bolker BM, Brooks ME, Clark CJ, Geange SW, Poulsen JR, Stevens MHH, and White J-SS. 2008. Generalized linear mixed models: a practical guide for ecology and evolution. Trends in Ecology and Evolution 24:127-135. 10.1016/j.tree.2008.10.008

Burnham KP, and Anderson DR. 2002. Model selection and multi-model inference: a practical information-theoretic approach. New York, NY: Springer.

Burnham KP, Anderson DR, and Huyvaert KP. 2011. AIC model selection and multimodel inference in behavioral ecology: some background, observations, and comparisons. Behavioral Ecology Sociobiology 65:23-35. 10.1007/s00265-010-1029-6

Campbell Grant EH, Lowe WH, and Fagan WF. 2007. Living in the branches: population dynamics and ecological processes in dendritic networks. Ecology Letters 10:165-175. 10.1111/j.14610248.2006.01007.x

Chiavazzo E, Isaia M, Mammola S, Lepore E, Ventola L, Asinari P, and Pugno NM. 2015. Cave spiders choose optimal environmental factors with respect to the generated entropy when laying their cocoon. Scientific Reports 5:7611. 10.1038/srep07611

Christiansen K. 1962. Proposition pour la classification des animaux cavernicoles. Spelunca 2:76-78.

Culver DC, and Pipan T. 2009. The biology of caves and other subterranean habitats. New York: Oxford University Press. p 254.

Culver DC, and Pipan T. 2014. Shallow Subterranean Habitats: Ecology, Evolution, and Conservation. New York, U.S.A.: Oxford University Press.

Culver DC, and White WB. 2005. Encyclopedia of caves. San Diego, California, U.S.A.: Elsevier Academic Press.

Curry PA, and Yeung NW. 2013. Predation on endemic Hawaiian land snails by the invasive snail Oxychilus alliarius. Biodiversity and Conservation 22:3165-3169. 10.1007/s10531-013-0576-3 
412

413

414

415

416

417

418

419

420

421

422

423

424

425

426

427

428

429

430

431

432

433

434

435

436

437

438

439

440

441

442

443

444

445

446

447

448

449

450

451

452

453

454

455

456

457

458

459

460

461

Di Russo C, Carchini G, Rampini M, Lucarelli M, and Sbordoni V. 1999. Long term stability of a terrestrial cave community. International Journal of Speleology 26:75-88.

Douglas B, Maechler M, Bolker B, and Walker S. 2015. Fitting Linear Mixed-Effects Models using lme4. Journal of Statistical Software 67:1-48. 10.18637/jss.v067.i01

Ecker R, and Moritz M. 1992. Meta menardi (Latr.) and Meta merianae (Scop.): On the biology and habitat of the commonest spiders in caves of the Harz, the Kyffhauser, Thuringa and the Zittau mountains. Mitteilungen aus dem Zoologischen Museum Berlin 68:345-350.

Fang Y. 2011. Asymptotic equivalence between cross-validations and Akaike Information Criteria in Mixed-Effects Models. Journal of Data Science 9:15-21.

Fenolio DB, Graening GO, Collier BA, and Stout JF. 2006. Coprophagy in a cave-adapted salamander; the importance of bat guano examined through nutritional and stable isotope analyses.

Proceedings of the Royal Society B 273:439-443. 10.1098/rspb.2005.3341

Fernández-Pérez J, Castro A, and Prieto CE. 2014. Arañas cavernícolas (araneae) de la región vascocantábrica: nuevos registros y actualizacion del conocimiento. Revista Ibérica de Aracnología 25:77-91.

Ficetola GF, Lunghi E, Canedoli C, Padoa-Schioppa E, Pennati R, and Manenti R. 2018. Differences between microhabitat and broad-scale patterns of niche evolution in terrestrial salamanders. Scientific Reports 8:10575. 10.1038/s41598-018-28796-x

Ficetola GF, Pennati R, and Manenti R. 2012. Do cave salamanders occur randomly in cavities? An analysis with Hydromantes strinatii. Amphibia-Reptilia 33:251-259.

Fiske I, and Chandler R. 2011. unmarked: an R package for fitting hierarchical models of wildlife occurrence and abundance. Journal of Statistical Software 43:1-23. http://www.jstatsoft.org/v43/i10/

Fritzén NR, and Koponen S. 2011. The cave spider Meta menardi (Araneae, Tetragnathidae) - occurrence in Finland and notes on its biology. Memoranda Soc Fauna Flora Fennica 87:80-86.

Gasparo F, and Thaler K. 1999. I ragni cavernicoli della Venezia Giulia (Italia nord-orientale) (Arachnida, Araneae). Atti e Memorie della Commissione Grotte "E Boegan" 37:17-55.

Gómez-Rodríguez C, Bustamante J, Díaz-Paniagua C, and Guisan A. 2012. Integrating detection probabilities in species distribution models of amphibians breeding in Mediterranean temporary ponds. Diversity and Distributions 18:260-272. 10.1111/j.1472-4642.2011.00837.x

Hervant F, Mathieu J, and Durand JP. 2000. Metabolism and circadian rhythms of the European blind cave salamander Proteus anguinus and a facultative cave dweller, the Pyrenean newt (Euproctus asper). Canadian Journal of Zoology 78.

Hijmans RJ, Cameron SE, Parra JL, Jonesc PG, and Jarvisc A. 2005. Very high resolution interpolated climate surfaces for global land areas. International Journal Of Climatology 25:1965-1978. 10.1002/joc. 1276

Hörweg C, Blick T, and Zaenker S. 2012. The large cave spider, Meta menardi (Araneae: Tetragnathidae), spider of the year 2012. Arachnologische Mitteilungen 42:62-64. 10.5431/aramit4214

Juan C, Guzik MT, JAUME D, and Cooper SJB. 2010. Evolution in caves: Darwin's 'wrecks of ancient life' in the molecular era. Molecular Ecology 19:3865-3880. 10.1111/j.1365-294X.2010.04759.x

Kuznetsova A, Brockhoff B, and Christensen HB. 2016. lmerTest: Tests in Linear Mixed Effects Models. $\mathrm{R}$ package version 20-29.

Lopes Ferreira R, Mendes Martins V, Arantes Paixão E, and Souza Silva M. 2015. Spatial and temporal fluctuations of the abundance of Neotropical cave-dwelling moth Hypena sp. (Noctuidae, Lepidoptera) influenced by temperature and humidity. Subterranean Biology 16:47-60. 10.3897/subtbiol.16.5137

Lunghi E, Bruni G, Ficetola GF, and Manenti R. 2018a. Is the Italian stream frog (Rana italica Dubois, 1987) an opportunistic exploiter of cave twilight zone? Subterranean Biology 25:49-60. $10.3897 /$ subtbiol.25.23803 
Lunghi E, Cianferoni F, Ceccolini F, Mulargia M, Cogoni R, Barzaghi B, Cornago L, Avitabile D, Veith M, Manenti R, Ficetola GF, and Corti C. 2018b. Field-recorded data on the diet of six species of European Hydromantes cave salamanders. Scientific Data 5:180083. 10.1038/sdata.2018.83

Lunghi E, Corti C, Manenti R, Barzaghi B, Buschettu S, Canedoli C, Cogoni R, De Falco G, Fais F, Manca A, Mirimin V, Mulargia M, Mulas C, Muraro M, Murgia R, Veith M, and Ficetola GF. 2018c. Comparative reproductive biology of European cave salamanders (genus Hydromantes): nesting selection and multiple annual breeding. Salamandra 54:101-108.

Lunghi E, Ficetola GF, Mulargia M, Cogoni R, Veith M, Corti C, and Manenti R. 2018d. Batracobdella leeches, environmental features and Hydromantes salamanders. International Journal for Parasitology: Parasites and Wildlife 7:48-53. https://doi.org/10.1016/j.ijppaw.2018.01.003

Lunghi E, Manenti R, and Ficetola GF. 2014. Do cave features affect underground habitat exploitation by non-troglobite species? Acta Oecologica 55:29-35. http://dx.doi.org/10.1016/j.actao.2013.11.003

Lunghi E, Manenti R, and Ficetola GF. 2015. Seasonal variation in microhabitat of salamanders: environmental variation or shift of habitat selection? PeerJ 3:e1 122. 10.7717/peerj.1122

Lunghi E, Manenti R, and Ficetola GF. 2017. Cave features, seasonality and subterranean distribution of non-obligate cave dwellers. PeerJ 5:e3169. 10.7717/peerj.3169

MacKenzie DI, Nichols JD, Royle JA, Pollock KH, Bailey LL, and Hines JE. 2006. Occupancy estimation and modeling. Inferring patterns and dynamics of species occurrence. San Diego, California, U.S.A.: Academic Press.

Mammola S. 2017. Modelling the future spread of native and alien congeneric species in subterranean habitats - the case of Meta cave-dwelling spiders in Great Britain. International Journal of Speleology 46:427-437. https://doi.org/10.5038/1827-806X.46.3.2134

Mammola S, and Isaia M. 2014. Niche differentiation in Meta bourneti and M. menardi (Araneae, Tetragnathidae) with notes on the life history. International Journal of Speleology 43:343-353. http://dx.doi.org/10.5038/1827-806X.43.3.11

Mammola S, and Isaia M. 2017a. Rapid poleward distributional shifts in the European cave-dwelling Meta spiders under the influence of competition dynamics. Journal of Biogeography 44:27892797. 10.1111/jbi.13087

Mammola S, and Isaia M. 2017b. Spiders in cave. Proceedings of the Royal Society B 284:20170193. http://dx.doi.org/10.1098/rspb.2017.0193

Mammola S, Piano E, and Isaia M. 2016. Step back! Niche dynamics in cave-dwelling predators. Acta Oecologica 75:35-42. http://dx.doi.org/10.1016/j.actao.2016.06.011

Manenti R, Lunghi E, and Ficetola GF. 2015. Distribution of spiders in cave twilight zone depends on microclimatic features and trophic supply. Invertebrate Biology 134:242-251. 10.1111/ivb.12092

Manenti R, Lunghi E, and Ficetola GF. 2017. Cave exploitation by an usual epigean species: a review on the current knowledge on fire salamander breeding in cave. Biogeographia 32:31-46. $10.21426 / \mathrm{B} 632136017$

Manenti R, Siesa ME, and Ficetola GF. 2013. Odonata occurrence in caves: active or accidentals? A new case study. Journal of Cave and Karst Studies 75:205-209. 10.4311/2012LSC0281

Nentwig W, Blick T, Gloor D, Hänggi A, and Kropf C. 2018. Spiders of Europe. Available at https://araneae.nmbe.ch/ (accessed Version of 14/05/2018).

Nichols JD, Thomas L, and Conn PB. 2008. Inferences about landbird abundance from count data: recent advances and future directions. In: Thomson DL, Cooch EG, Evan G, and Conroy MG, eds. Modeling Demographic Processes in Marked Populations. New York: Springer, 1132.

Novak T, Perc M, Lipovšek S, and Janžekovič F. 2012. Duality of terrestrial subterranean fauna. International Journal of Speleology 41:181-188. http://dx.doi.org/10.5038/1827-806X.41.2.5

Novak T, Tkavc T, Kuntner M, Arnett AE, Lipovšek Delakorda S, Perc M, and Janžekovič F. 2010. Niche partitioning in orbweaving spiders Meta menardi and Metellina merianae (Tetragnathidae). Acta Oecologica 36:522-529. 10.1016/j.actao.2010.07.005 
511

Pastorelli C, and Laghi P. 2006. Predation of Speleomantes italicus (Amphibia: Caudata: Plethodontidae) by Meta menardi (Arachnida: Araneae: Metidae). Atti del $6^{\circ}$ Congresso Nazionale della Societas Herpetologica Italica (Roma, 27IX-1X2006). Roma, 45-48.

Pavan M. 1944. Appunti di biospeleologia I. Considerazioni sui concetti di Troglobio, Troglofilo e Troglosseno. Le Grotte d'Italia 5:33-41.

Pinheiro J, Bates D, DebRoy S, Sarkar D, and Team RC. 2016. nlme: Linear and Nonlinear Mixed Effects Models. $R$ package version 31-128. http://CRAN.R-project.org/package=nlme.

Pollock KH, Nichols JD, Simons TR, Farnsworth JL, Bailey LL, and Sauer JR. 2002. Large scale wildlife monitoring studies: statistical methods for design and analysis. Environmetrics 13:105-119. https://doi.org/10.1002/env.514.

R Core Team. 2016. R: a language and environment for statistical computing. Vienna, Austria: R Foundation for Statistical Computing.

Richards SA, Whittingham MJ, and Stephens PA. 2011. Model selection and model averaging in behavioural ecology: the utility of the IT-AIC framework. Behavioral Ecology and Sociobiology 65:77-89. 10.1007/s00265-010-1035-8

Romero A. 2009. Cave Biology. Cambridge, UK: Cambridge University Press.

Romero A. 2011. The Evolution of Cave Life. American Scientist 99:144-151.

Sket B. 2008. Can we agree on an ecological classification of subterranean animals? Journal of Natural History 42:1549-1563. 10.1080/00222930801995762

Smithers P. 2005a. The diet of the cave spider Meta menardi (Latreille 1804) (Araneae, Tetragnathidae). Journal of Arachnology 33:243-246.

Smithers P. 2005b. The early life history and dispersal of the cave spider Meta menardi (Latreille 1804), Tetragnathidae. Bulletin of the British Arachnological Socity 13:213-216.

Smithers P, and Smith FM. 1998. Observations on the behaviour of second instars of the cave spider Meta menardi (Latreille, 1804). Newsletter of the British Arachnological Society 81:4-5.

Smithson PA. 1991. Inter-relationships between cave and outside air temperatures. Theoretical and Applied Climatology 44:65-73.

Tercafs R. 1972. Biométrie spatiale dans l'écosystème souterraine: repartition du Meta menardi Latr. (Argiopidae). International Journal of Speleology 4:351-355.

Trajano E, and de Carvalho MR. 2017. Towards a biologically meaningful classification of subterranean organisms: a critical analysis of the Schiner-Racovitza system from a historical perspective, difficulties of its application and implications for conservation. Subterranean Biology 22:1-26. 10.3897/subtbiol.22.9759

Venables WN, and Ripley BD. 2002. Modern Applied Statistics with S. Fourth Edition. New Yourk: Springer. 


\section{Table $\mathbf{1}$ (on next page)}

The best five AICc models relating the presence of Meta bourneti (Meta spiders, Adults and Juveniles).

In both GLMM and GLM analyses, the presence of the respective studied group was used as a dependent variable. Independent variables were: Height, Width and wall Heterogeneity (Het) of sectors, Season of the survey, average Temperature (Temp), Humidity (Hum) and Illuminance (Lux) recorded inside each sector. Interactions ( ${ }^{\mathrm{x}}$ ) between season and microclimatic features (temperature, humidity, illuminance) were added as further independent variables. In GLMM analyses both sector and cave identity were used as random factors; in GLMs cave identity was included as an additional independent variable. The " $X$ " indicates the presence of the variable into the respective AICc model; - indicates that the variable was not used in the analyses. 
Independent variables included in the model

df AICc

$\triangle$-AICc

Weight

\begin{tabular}{|c|c|c|c|c|c|c|c|c|c|c|c|c|c|c|c|}
\hline & Height & Width & Het & Season & Cave & Temp & Hum & Lux & $\operatorname{Temp}^{\times} \mathbf{S}$ & Hum $^{\times} \mathbf{S}$ & $\operatorname{Lux}^{\times} \mathbf{S}$ & & & & \\
\hline \multicolumn{16}{|l|}{ GLMM } \\
\hline \multicolumn{16}{|l|}{ Meta spiders } \\
\hline & $\mathbf{X}$ & & & $\mathbf{X}$ & - & & $\mathbf{X}$ & $\mathbf{X}$ & & & $\mathbf{X}$ & 12 & 456.9 & $\mathbf{0}$ & 0.254 \\
\hline & X & & X & X & - & & X & $X$ & & & $\mathrm{X}$ & 13 & 457.3 & 0.41 & 0.207 \\
\hline & $\mathrm{X}$ & & & $\mathrm{X}$ & - & & $\mathrm{X}$ & $\mathrm{X}$ & & $\mathrm{X}$ & $\mathrm{X}$ & 15 & 457.8 & 0.91 & 0.161 \\
\hline & $\mathrm{X}$ & $\mathrm{X}$ & & $\mathrm{X}$ & - & & $\mathrm{X}$ & $\mathrm{X}$ & & & $\mathrm{X}$ & 13 & 458.2 & 1.34 & 0.130 \\
\hline & $\mathrm{X}$ & & $\mathrm{X}$ & $\mathrm{X}$ & - & & $\mathrm{X}$ & $\mathrm{X}$ & & $\mathrm{X}$ & $\mathrm{X}$ & 16 & 458.3 & 1.42 & 0.125 \\
\hline \multicolumn{16}{|l|}{ Adults } \\
\hline & & & $\mathbf{X}$ & & - & & & $\mathbf{X}$ & & & & 5 & 220 & $\mathbf{0}$ & 0.220 \\
\hline & & & $X$ & & - & & $X$ & $X$ & & & & 6 & 220.2 & 0.17 & 0.202 \\
\hline & X & & & & - & & & $X$ & & & & 5 & 220.6 & 0.56 & 0.166 \\
\hline & & & & & - & & & $\mathrm{X}$ & & & & 4 & 220.9 & 0.89 & 0.141 \\
\hline & $\mathrm{X}$ & & $X$ & & - & & & $X$ & & & & 6 & 220.9 & 0.95 & 0.137 \\
\hline Juvemines & $\mathbf{X}$ & & & $\mathbf{X}$ & - & $\mathbf{X}$ & $\mathbf{X}$ & $\mathbf{X}$ & & & $\mathbf{X}$ & 13 & 344.4 & 0 & 0.246 \\
\hline & $\mathrm{X}$ & & & $X$ & - & & $\mathrm{X}$ & $\mathrm{X}$ & & $X$ & $\mathrm{X}$ & 15 & 345.1 & 0.74 & 0.171 \\
\hline & X & & & X & - & & $X$ & $X$ & & & X & 12 & 345.2 & 0.81 & 0.164 \\
\hline & $X$ & & & $\mathrm{X}$ & - & X & $\mathrm{X}$ & & & X & & 12 & 345.4 & 0.96 & 0.153 \\
\hline & $\mathrm{X}$ & & & $X$ & - & & $X$ & & & $X$ & & 11 & 345.4 & 0.98 & 0.151 \\
\hline \multicolumn{16}{|l|}{ GLM } \\
\hline \multicolumn{16}{|l|}{ Meta spiders } \\
\hline & $\mathbf{X}$ & & & $\mathbf{X}$ & $\mathbf{X}$ & & $\mathbf{X}$ & & & & & 11 & 149.3 & $\mathbf{0}$ & 0.357 \\
\hline & X & & X & X & $X$ & & $X$ & & & & & 12 & 150.9 & 1.53 & 0.166 \\
\hline & $\mathrm{X}$ & X & & X & X & & $\mathrm{X}$ & & & & & 12 & 151 & 1.66 & 0.156 \\
\hline & $\mathrm{X}$ & & & $X$ & $X$ & & $\mathrm{X}$ & $X$ & & & & 12 & 151.3 & 2.02 & 0.130 \\
\hline & $X$ & & & $X$ & $X$ & $X$ & $X$ & & & & & 12 & 151.5 & 2.17 & 0.121 \\
\hline Adurts & $\mathbf{X}$ & & & $\mathbf{X}$ & $\mathbf{X}$ & & & $\mathbf{X}$ & & & & 11 & 77.3 & 0 & 0.233 \\
\hline & & & $\mathrm{X}$ & $\mathrm{X}$ & $\mathrm{X}$ & & & $\mathrm{X}$ & & & & 11 & 77.5 & 0.22 & 0.209 \\
\hline & $X$ & & X & X & $\mathrm{X}$ & & & $X$ & & & & 12 & 77.7 & 0.45 & 0.186 \\
\hline & & & & $X$ & $X$ & & & $\mathrm{X}$ & & & & 10 & 79.2 & 0.95 & 0.145 \\
\hline \multirow{2}{*}{\multicolumn{3}{|c|}{ Juveniles }} & & $\mathrm{X}$ & $\mathrm{X}$ & & & $X$ & & & & 12 & 78.5 & 1.15 & 0.131 \\
\hline & $\mathbf{X}$ & & & $\mathbf{X}$ & $\mathbf{X}$ & & $\mathbf{X}$ & & & & & 11 & 102.5 & $\mathbf{0}$ & 0.315 \\
\hline & $X$ & & & $X$ & $\mathrm{X}$ & $\mathrm{X}$ & $X$ & & & & & 12 & 103.1 & 0.56 & 0.238 \\
\hline & X & & & $\mathrm{X}$ & X & & $X$ & $X$ & & & & 12 & 104.4 & 1.93 & 0.120 \\
\hline & $\mathrm{X}$ & X & & $\mathrm{X}$ & $X$ & & $X$ & & & & & 12 & 104.5 & 1.96 & 0.118 \\
\hline & $\mathrm{X}$ & & $\mathrm{X}$ & $\mathrm{X}$ & $\mathrm{X}$ & & $\mathrm{X}$ & & & & & 12 & 105 & 1.99 & 0.117 \\
\hline
\end{tabular}

1 


\section{Table 2 (on next page)}

Parameters related to the presence of Meta bourneti spiders.

For each group (Meta spiders, Adults and Juveniles) the significance of variables included in the relative best AICC model of the respective analysis. Shaded variables are those included in the best model of both GLMM and GLM. 


\begin{tabular}{|c|c|c|c|c|c|c|c|}
\hline & \multirow[b]{2}{*}{ Factor } & \multicolumn{3}{|c|}{ GLMM } & \multicolumn{3}{|c|}{ GLM } \\
\hline & & $\beta$ & $\chi^{2}$ & $P$ & $\beta$ & $\chi^{2}$ & $P$ \\
\hline \multicolumn{8}{|l|}{ Meta bourneti } \\
\hline & Season & & 10.33 & 0.016 & & 4.99 & 0.173 \\
\hline & Cave & & & & & 12.08 & 0.034 \\
\hline & Height & 0.28 & 16.12 & $<0.001$ & 0.27 & 17.51 & $<0.001$ \\
\hline & Humidity & 13.29 & 13.87 & $<0.001$ & 11.23 & 9.64 & 0.002 \\
\hline & Illuminance & -1.71 & 0.01 & 0.917 & & & \\
\hline & Illuminance ${ }^{\times}$Season & & 14.57 & 0.002 & & & \\
\hline \multicolumn{8}{|l|}{ Adults } \\
\hline & Season & & & & & 0.86 & 0.834 \\
\hline & Cave & & & & & 5.65 & 0.342 \\
\hline & Height & & & & 0.24 & 3.75 & 0.053 \\
\hline & Wall_Irreg & 5.18 & 2.92 & 0.087 & & & \\
\hline & Illuminance & -2.58 & 7.52 & 0.006 & -3.03 & 10.06 & 0.001 \\
\hline \multicolumn{8}{|l|}{ Juveniles } \\
\hline & Season & & 18.7 & $<0.001$ & & 8.9 & 0.031 \\
\hline & Cave & & & & & 14.14 & 0.015 \\
\hline & Height & 0.29 & 14.65 & $<0.001$ & 0.28 & 13.73 & $<0.001$ \\
\hline & Temperature & 0.34 & 2.89 & 0.089 & & & \\
\hline & Humidity & 17.14 & 16.25 & $<0.001$ & 13 & 8.19 & 0.004 \\
\hline & Illuminance & -1.5 & 0.08 & 0.779 & & & \\
\hline & Illuminance ${ }^{x}$ Season & & 10.57 & 0.014 & & & \\
\hline
\end{tabular}

1 


\section{Figure 1}

Map of the surveyed area.

The map shows the surveyed caves in Monte Albo (Sardinia, Italy). Green circles (and the respective number) indicate the caves in which was observed Meta bourneti spiders; the red circle indicates the cave in which the species was not observed.

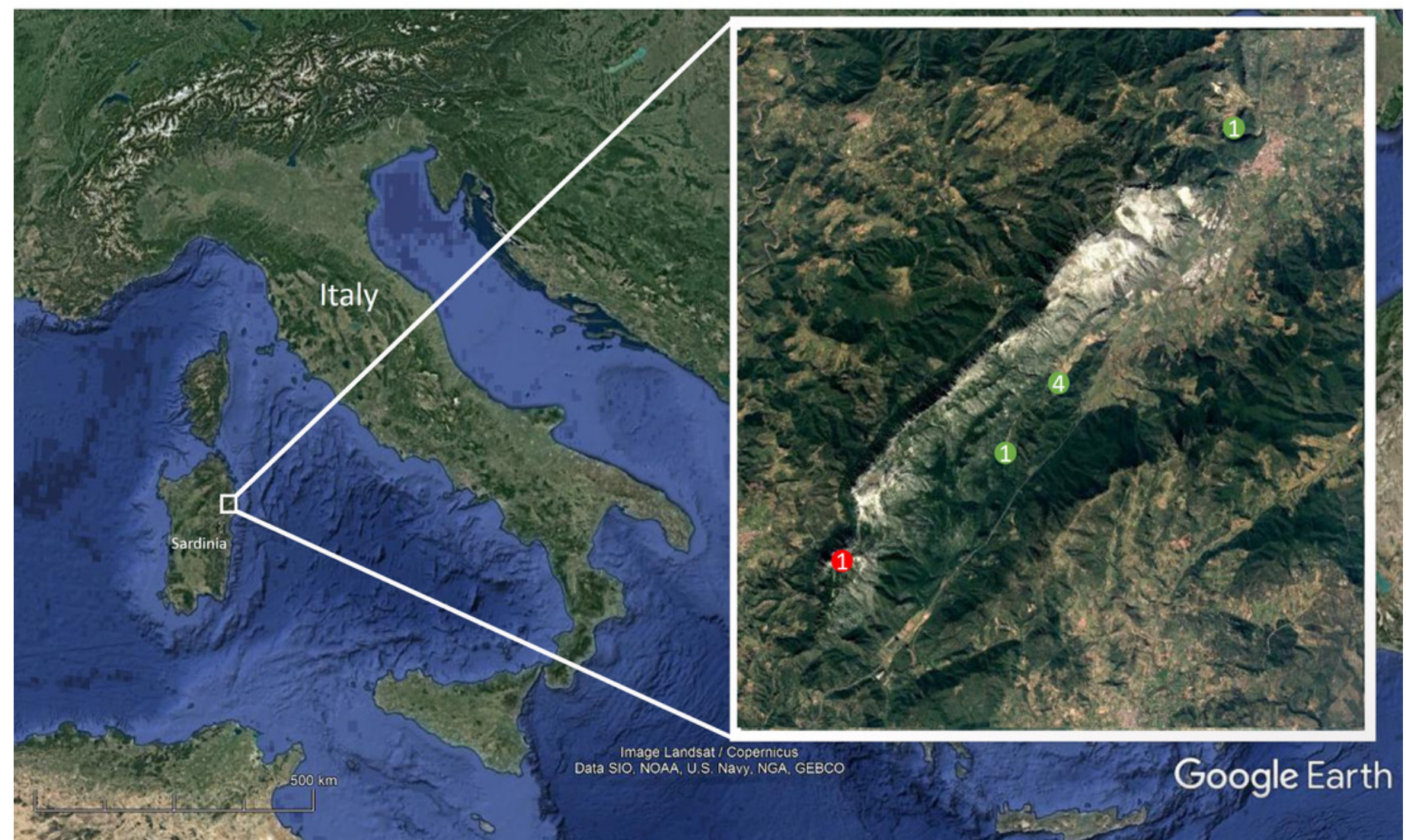


Figure 2

Observed abundance of Meta bourneti spiders in Monte Albo's caves.

Seasonal number of observed spiders is given separating adults (dark grey) and juveniles (light grey) from autumn 2015 to summer 2016.

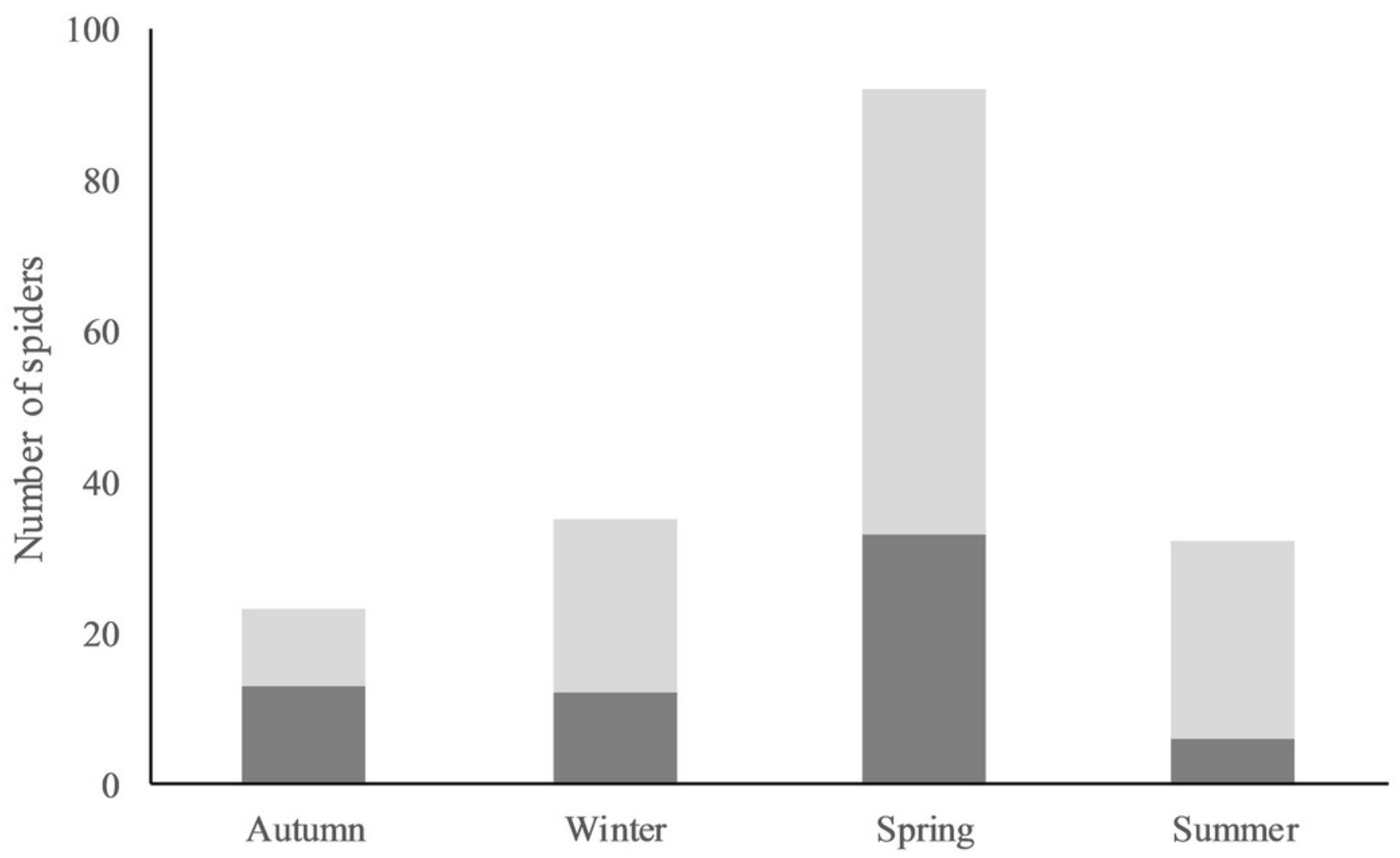


Figure 3

Boxplots indicating the vertical distribution of Meta bourneti along cave walls.

Differences in vertical distributions of spiders (average height above the cave floor) among seasons. Horizontal bar inside the box represents the median.

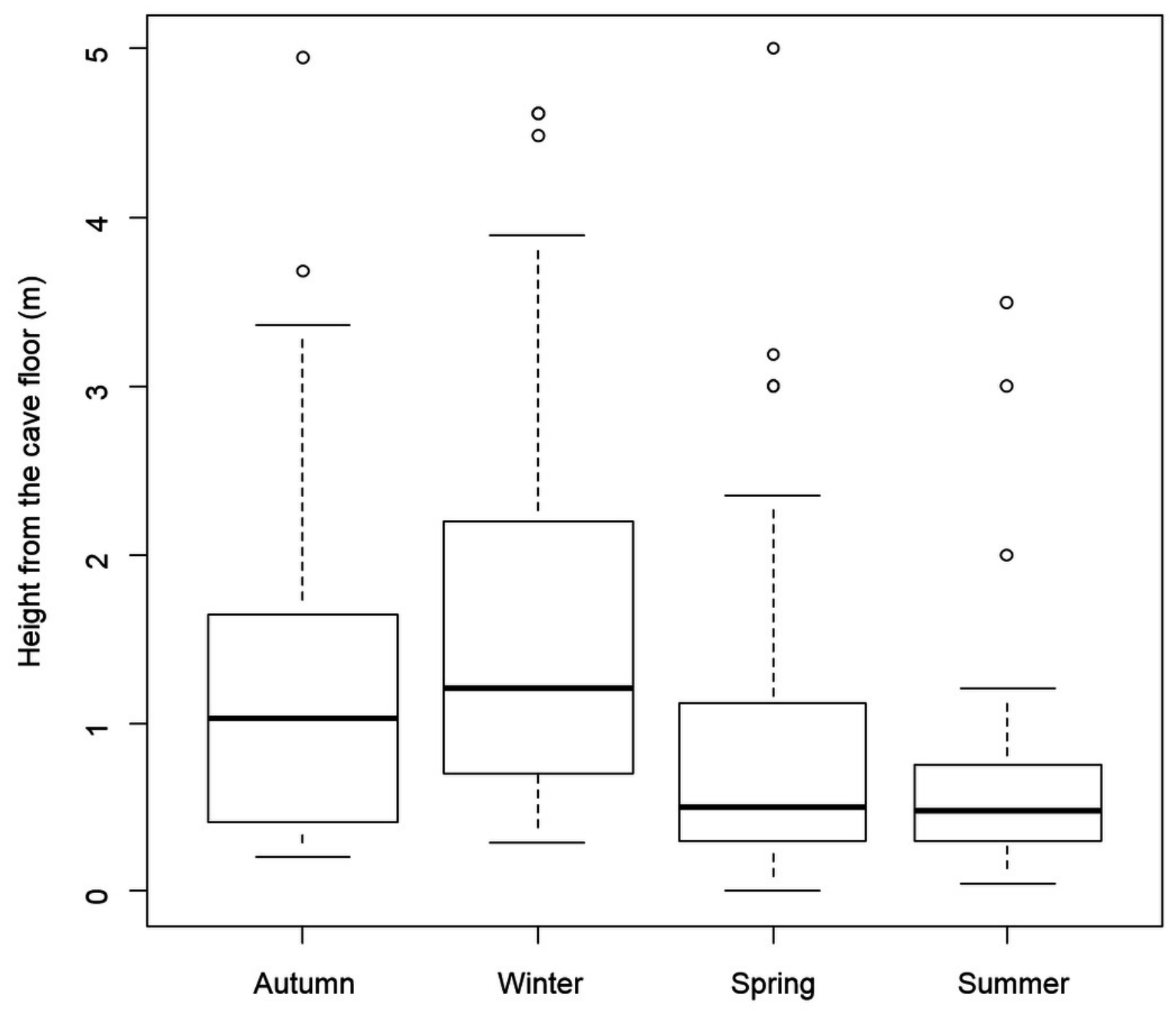

